\title{
Environmentalizing the curriculum: a critical dialogue of south-north framings
}

\author{
Phillip G. Payne* \\ Cae Rodrigues ${ }^{* *}$
}

\begin{abstract}
The question of how the environmentalization of the curriculum might occur in the higher education sector in a sustainable manner has become a local, national, regional and global concern for environmental educators, specifically, and educators, generally. The contemporary ACES framework includes ten characteristics of "environmentalization" deemed appropriate for incorporation into teacher education programs, and has been adopted by some Brazilian public universities among others in Latin America and Europe. This highly influential framework was developed by a group of "Latin" academics from Europe and Latin America. We bring that framework into critical dialogue with the development of the "socially critical" and "post-critical" perspectives in environmental education curriculum and framings of its research, as this critical discourse has developed in the Anglo-speaking North over the past thirty years. We reflexively identify a number of key similarities and differences in this South-North dialogue. Brazilian educators, curriculum specialists and researchers, for whom this article is primarily written, might further refine the critical possibilities of the ACES framework in their efforts to environmentalize the curriculum. More broadly, this article exemplifies a non-colonial approach to globalizing the discourse of environmental education.
\end{abstract}

Keywords: Environmental Education. Curriculum Theory. Higher Education.

\footnotetext{
* Prof. Dr. Monash University (Australia)

** Ms. Federal University of São Carlos (Brazil).
} 


\section{Introduction}

Since the formalization of the environmental education field in the 1970s, primarily as a consequence of a series of United Nations conferences, concerned educationalists, curriculum theorists and pedagogical developers working in universities and schools around the world have confronted major questions about the field and its progress. There are many curriculum and pedagogical "currents" in environmental education (SAUVÉ, 2005). Challenging questions are also being posed about the "nature" of knowledge in environmental education and how it is being framed, generated, or produced in environmental education research (PAYNE, 2009). Worries are being expressed from within the field about the mixed purposes or "identity" of the field and the forms in which such knowledge conceptions and constructions can be delivered or implemented in different geographical and demographic and historical-cultural settings. These basic concerns about curriculum, pedagogy and research are exacerbated by a global knowledge condition (LYOTARD, 1984) in which there are now deep concerns about how environmental education is being enacted, taken up and embodied by its various audiences in the neo-liberal inspired "production" of environmental/ecological knowledge transfer (REID; PAYNE, 2012). Politically, we appear to have entered a phase of global history that Bludhorn (2011) refers to as "post-ecologism" in which the "unsustainable" politics of "sustainability" have been naturalized and, consequently, normalized in a "post-democratic" global condition.

In this article, we are mainly concerned with two of the many persistent issues that have occupied the attention of environmental education scholars, researchers, curriculum theorists and pedagogues working in higher education settings, namely: a) the disciplinary, multi-disciplinary, cross-disciplinary, interdisciplinary and transdisciplinary natures of "environmental" and "educational" knowledge; and b) the socio-environmental design of curricula that aim to either integrate or infuse such knowledge into pre-existing forms (or disciplines) or/and develop distinctive "stand alone" forms of environmental education.

Of course, these two concerns are interrelated. We focus on the latter. And, for the purposes here, we focus our cosmopolitan "case study" attention on a highly contemporary and influential programme that is now having significant effects and, possibly, evaluative impacts on the environmentalization of higher education in Brazil and other Latin American and European countries. This 
recent development is named the "Curricular Environmentalization in Higher Education Programme: intervention design and analysis of the process". It was developed by the ACES Network ${ }^{1}$ between 2002 and 2003 and was funded by the European Commission under the $\mathrm{ALFA}^{2}$ programme.

Bringing together and debating issues relevant to the environmentalization of curriculum in different social and cultural realities of education, the Network developed a schematic circular diagram that represented a consensus among the researchers about what constitutes the key "characteristics" of an "environmentalized" curriculum study. These characteristics are made up of a set of features that best represent "the domains that should be considered in the evaluation of the degree of environmentalization of the curriculum, a set of approaches that are considered simultaneously, once an approximation has been made to the object of study" (JUNYENT, 2003, p. 42, our translation).

These characteristics resulted from a (limited or restricted) international collaboration between researchers in the curricular environmentalization field. Researchers from eleven universities from seven different European and Latin American countries ${ }^{3}$ were represented in this "globalizing" discussion. Each contributed from their central, or national, reference framework. The ACES framework can, therefore, be considered to be one of the major contemporary benchmarks in regard to the (re)framing of curriculum environmentalization in higher education in Brazil and other countries represented in its formulation.

For the purposes here, we believe that the ACES framework exhibits underlying normative qualities that, possibly, are "critical" when considered as part of an emerging (globalizing) imaginary for curriculum reform in an environmentalized approach to education. We are particularly worried about the neo-liberal rise of the corporate university in many parts of the world and the potential that environmentalizing the curriculum might undermine the critical aspirations of environmental education and trivialize curriculum in ways that they become a 'greenwashed' form of education. Our particular approach to fostering a heightened "criticality" within this globalizing context of educational and curriculum reform is to bring the ACES characteristics into constructive dialogue with the "socially critical" and "post-critical" framings of environmental education and its research as those framings have historically developed in the Anglo-speaking North since the late 1980s.

This "South-North" dialogue we offer about the critical curriculum design of environmental education is timely. First, by bringing the "Latin" 
inspired ACES framework into conversation with the key characteristics of the "Anglo" socially critical and post-critical framings, a heightened reflexivity can be anticipated about the two different linguistically driven geo-cultural/ historical epistemologies (CANAPARO, 2009) and how they converge and diverge, or are silent. Second, as global environmental problems and issues like anthropogenic climate change and its consequences (regionally, nationally, locally) become more self evident, there is increasing urgency in fostering between those different cultural/historical geo-epistemologies a "globalizing imaginary" for educational research (KENWAY; FAHEY, 2009) that, in a more cosmopolitan (SUND; OHMAN, 2011) and globally democratic way (JICKLING; WALS, 2008), aims to avoid or prevents colonial and neo-liberal inspired "one world" only tendencies in the environmentalization of education (LOTZ-SISITKA, 2010, PAYNE, 2010).

Specifically, our dialogue will describe, compare and contrast the schematically declared characteristics of the "Curricular Environmentalization in Higher Education Programme" with the underlying principles of the socially critical and post-critical framings of environmental education established from the 1980s through to the present.

First, we historically contextualize the ACES "Curricular Environmentalization in Higher Education Programme". We then analyze documents published by the Network during the development of the programme, giving special consideration to its 10 characteristics for an environmentalized curriculum. That analysis provides the basis for a critical interpretation of the ACES framework and, therefore, a basis of comparison with other conceptual and theoretical starting points such as the socially critical principles and post-critical dimensions. In our tentative conclusion, we identify a number of broad commonalities in this South-North dialogue and elaborate briefly on five points of difference.

Acknowledging the risks of putting together theories linguistically, textually and socially constructed over time and space in different geographical / cultural settings, we felt it was important to write this paper as an emerging global or cosmopolitan expression of the "environmental happening"“ uttered by programmes that aim to bring together a range of international developments in the field, such as the one developed by the ACES Network. By doing so, we can potentially create a future research space that is valuable not only for considering the further development of curricular environmentalization 
"diagnostic tools", such as the 10 characteristics developed by the ACES Network, but also the overall development of curricular environmentalization that will contribute imaginatively to the epistemological (re)positioning of the fields of environmental education and education and their sustainability.

\section{The "Curricular Environmentalization in Higher Education Programme" and the ACES Network}

The "Curricular Environmentalization in Higher Education Programme" developed by the ACES Network was funded by the European Commission under ALFA, a programme of cooperation between higher education institutions of the European Union and Latin America. The ALFA programme began in 1994 with the aim of strengthening cooperation in the field of higher education. ALFA co-finances projects aimed at developing the capacity of individuals and institutions (universities and other relevant organizations) and the promotion of academic cooperation between the two regions.

The "Curricular Environmentalization in Higher Education Programme" was part of the second phase of the ALFA Programme (ALFA II - 2000-2006), which had a total of 10 selection rounds, representing contributions of $€ 54.6$ million. This total was distributed to 225 approved projects carried out by 770 institutions, which were broken down by networks with an average of 9 institutions from Latin America and Europe being successful in their application for funds. The ALFA programme is currently running its third phase (ALFA III -2007-2013), which has a significant increase in the budget of contributions (€85 million), as well as a new and modernized structure of the programme 5 .

At this point we feel it is important to highlight that the participating institutions in the "Curricular Environmentalization in Higher Education Programme" were self selected. The initial proposition was elaborated by Universitat Autònoma de Barcelona (Spain), soon joined by Universidade Federal de São Carlos (Brazil). The other universities joined the project later by invitation, creating the strong international appeal needed for submitting the programme to ALFA. This has important political/epistemological/theoretical implications in the overall framing of the programme, which has to be taken into consideration by a critical analysis. We also acknowledge here that within the Brazilian discourse of environmental education, in particular, there historically is a "critical" perspective that draws strongly from Freirean critical pedagogy 
and (maybe on a smaller scale, but certainly significant) Morin's theory on "complexity", as found, for example, in the book "Identidades da Educação Ambiental Brasileira" (Identities of Brazilian Environmental Education), edited by the Brazilian Ministry of Environment in 20047.

The essential starting point of the highly contemporary "Curricular Environmentalization in Higher Education Programme" was a first face-toface meeting of the ACES Network during the "1st International Seminar on Sustainability in Higher Education (ACES Network)", held at the Technical University of Hamburg-Harburg (Germany) from February $27^{\text {th }}$ to March $3^{\text {rd }}, 2002$.

The main purpose of this first meeting, in addition to defining and establishing the dynamics of the Network, was to develop analysis methodologies to assess the degree of curricular environmentalization of higher education programmes in Latin America and Europe, based on the interdisciplinary work of the participating researchers and universities. In that sense, the main objectives were: (a) progress towards a definition of "curricular environmentalization" that would have validity in different realities depicted in ALFA, consequently, in the seminar that would serve to frame the common programme; (b) defining the characteristics that an "environmentalized study" should have; (c) designing criteria and methods of diagnosis for evaluating the degree of curricular environmentalization of any higher education study; (d) creating a space for the exchange of knowledge and experience between experts in curricular environmentalization; (e) working in a participatory manner to enhance this knowledge / experience exchange; (f) encouraging interdisciplinary and intercultural work, taking into account the different formations, specialties and backgrounds of the participating researchers; (g) thinking about the most appropriate methodology and criteria to apply in each reality.

Prior to the Hamburg seminar, the researchers of each of the participating universities drafted a document describing the physical structure of their institution, as well as what was being done in terms of greening the university and how this was being done. These documents are part of the first publication of the ACES Network under the ALFA programme (ARBAT; GELI, 2002).

The points dealt with by each represented university were: (a) establishing a definition of the concept of curricular environmentalization. This concept should involve what was already being carried out in terms of "university greening" in the institution, as well as what was being planned for the 
future (including within the time length of the programme); (b) defining the characteristics that an environmentalized study of curriculum in higher education should consider; (c) conducting a diagnosis of the degree of curricular environmentalization on cases researchers had heard of, or had previously worked on.

Following the preparation and dissemination of the various reports, the University of Girona (Spain), as programme coordinator (consistent with the fact that the initial proposal for the programme came from this institution), prepared a "groundwork" (base) document for discussion at the seminar in Hamburg. It is important to highlight the great range of different perspectives, points of departure and knowledge present in the contributions made by the participating universities (ARBAT; GELI, 2002). This diversity of input was needed for the consensual development of a rigorous tool to describe, analyze and evaluate curriculum environmentalization and that would be capable of bringing together these various perspectives. At the same time it needed to be a valuable and useful resource, capable of effectively setting the grounds for the upcoming debates and thus progress in this common ACES programme.

The final groundwork document consisted of two parts, in response to the questions presented to the universities represented at Hamburg: (a) a first overall draft of the definition of curricular environmentalization; (b) a first overall draft of the definition of the characteristics of an environmentalized study. This document constituted the creation of a space where concepts and characteristics could be agreed upon, ratified by the contributors and accessed by others with an interest in the environmentalization of curriculum in higher education in a unifying manner, representing the great diversity of realities.

In the search for theoretical language that would respect the different cultural realities and consequent plurality of views of the participating institutions, as well as the essentially interdisciplinary character of curricular environmentalization, the process of defining the 10 characteristics had as central reference curricular practices, given that through them different elements, aspects and nuances of culture are contextualized into the undergraduate and postgraduate structures (JUNYENT, 2003). However, each of the characteristics also referred to research, extension, education programs, disciplinary units and standards of institutional dynamics.

After the Hamburg meeting, a second collective meeting was held in Mendoza (Argentina) in September 2002. At this meeting a schematic "circular 
diagram" was developed as the chosen "summary", or as a conceptual way to represent the 10 "framing" characteristics of an environmentalized study collaboratively constructed by the Network.

Figure 1: Circular diagram with 10 characteristics of an environmentalized study

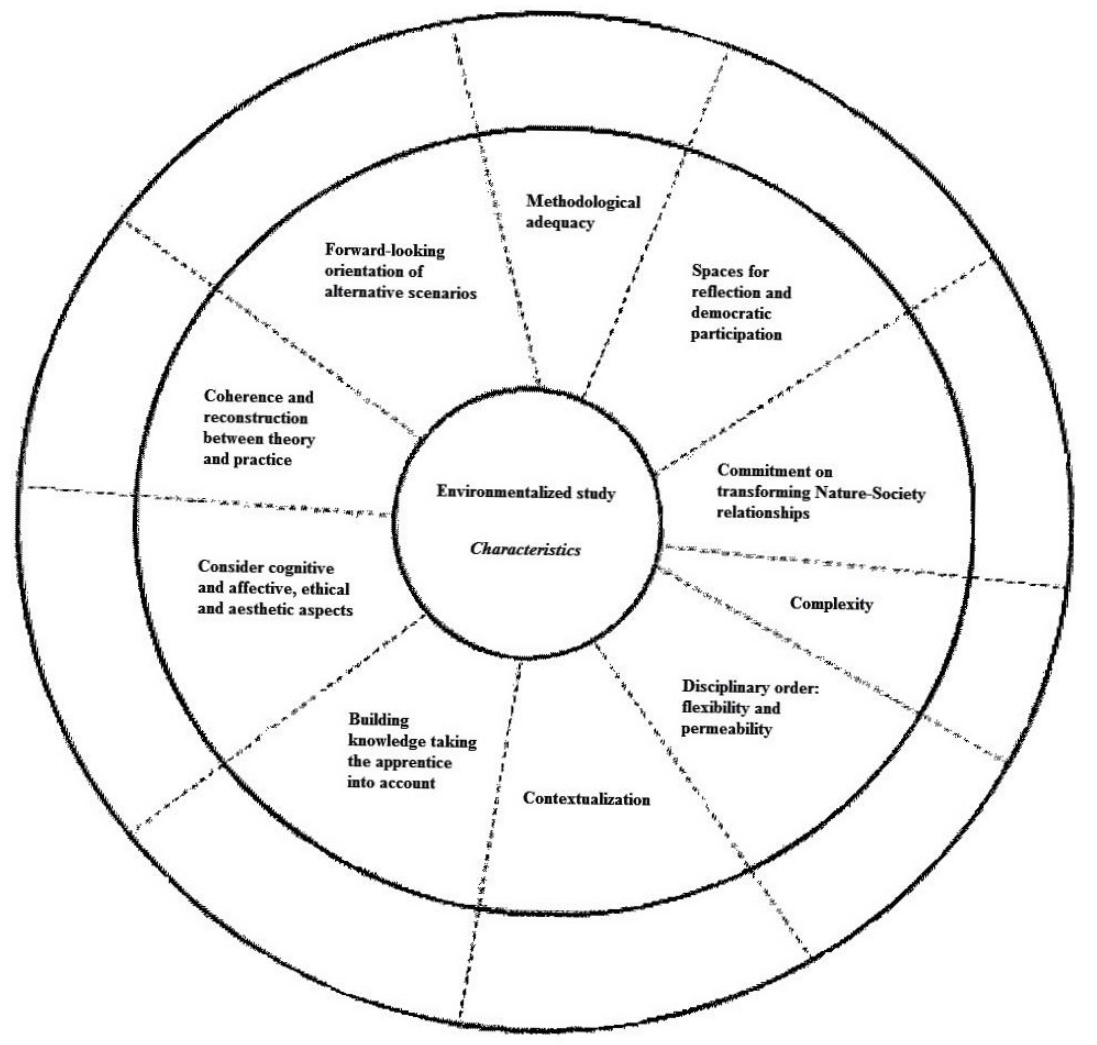

Source: JUNYENT, 2003, p. 41.

As an "international" document, the ACES Networks' model both indicates and reflects different concepts and proposals surrounding the debates about curriculum, but focusing on the environmentalization of higher education. In fact, it brings forward some of the acclaimed needs expressed by the academic community in seminars about university and environment and by international treaties on environmental / sustainability education (PAVESI, 
2007).

The circular diagram is presented in the Networks' second publication (JUNYENT, 2003). A third publication presents the practical interventions developed by each university regarding the greening of the institution (including curricular environmentalization) using the ACES Network guidelines (model) (GELI, 2003). We do not analyze that document here. Nor do we discuss the fourth and final publication, which closes the programme of curricular environmentalization of higher education developed by the ACES Network. It presented the results of the practical interventions (diagnostics) developed by the universities, as well as the conclusions of all works developed by the researchers of the Network during the programme (GELI, 2004).

To facilitate the synthesis of the actions taken by the participating universities, the last meeting of the ACES Network was held in November 2003 in the University of Girona (Spain). It promoted a debate in which the researchers could express their views about the development of the programme and the various works in progress at different participating universities resulting in a collective reflection about the Networks' aspirations, expectations and accomplishments.

\section{The 10 characteristics of the ACES Network for an environmentalized study}

To better understand the Networks' 10 characteristics, methodologically and for interpretive purposes, we drafted a summarized description of each characteristic. These are based on the descriptions presented by the participating universities in the Networks' second publication (JUNYENT, 2003). There are difficulties and risks associated with language translations, so we used English terms whose meanings most closely approximated the original Spanish and Portuguese words in the original documents. This interpretive process is a methodological concern and limit that should always be taken into consideration when aiming globally for a "common language" and "understanding" of, for example, the focus on curricular environmentalization and creating a critical dialogue of South-North perspectives 8 .

1. Commitment on transforming Nature-Society relationships: this characteristic focuses the role of curriculum on creating the necessary educational conditions for transforming our existence in society. It 
links fields of human thinking and acting with tension points in the human-nature relationship. In this sense, researchers of ACES Network highlight:

- The importance of social context as a reference to "ways of thinking";

- Active participation in developing the building blocks of policies that aim to improve the quality of life in society;

- The (re)construction of worldviews that lead to transformative actions;

- Social practices that more clearly define and reduce discriminatory and predatory relationships;

- Commitment to transformations that move towards sustainable practices;

- Preparing students to critically face environmental issues.

2. Complexity: this characteristic refers mainly to the understanding of the world from the paradigm of "complexity". It is based on the promotion of a complex vision of reality, implying an interpretation that considers the chaotic, uncertain and systemic organization of the relations that shape the natural and social spheres. To this end, researchers of ACES Network highlight:

- The enhancement of dialogic principles;

" The construction of knowledge through "complementation", not "fragmentation";

" The interpretation of the world through "open attitudes", putting things under different perspectives, recognizing the existence of uncertainties, paradoxes and contradictions.

3. Disciplinary order: flexibility and permeability: this characteristic is associated with proposals for the reorganization of the academic curriculum, based on the idea of curricular flexibility. According to the researchers of the ACES Network this can be accomplished by:

- Openness to different disciplines through critical reflection, making way for emotions and decision making;

- Acknowledging disciplinary limitations for the study of environmental 
problems, and predicting ways to overcome them;

- Scientific "interculturality"; this involves the orientation of cognitive processes by facing the perception and interpretation of environmental complexity through a variety of disciplines, aiming to foster transversal, meaningful, humanistic and constructive learning;

- Confirming that educational contents are suitable to sociocultural contexts;

- Dialogue between diversified philosophical / metaphysical / epistemological ideas and positions;

- Openness to interactions between different courses, disciplines and professionals from different areas of knowledge.

4. Contextualization: the main idea of this characteristic focuses on contextualizing local issues (spatially thought, as "surroundings") and global issues (Local-Global-Local/Global-Local-Global), contemplating the analysis of environmental conflicts in the appropriate spatiotemporal context. To this end, the researchers of ACES Network suggest:

- Investigating local events considering the social and environmental context, which includes social circumstances and the political, economic, cultural and eco-physical context; while simultaneously considering the global context in which these events are immersed;

" Not restricting environmental conflicts to the "here and now"; associate topics of a discipline to the immediate and global surrounding, situating the topic in the present, comparing it with the past and anticipating future scenarios.

5. Building knowledge taking the subject into account: this characteristic refers to the importance of using a variety of strategies to encourage the active participation of students in the process of environmental education, especially regarding meaningful learning. In this sense, the strategies used for elaborating the academic units are put under the spotlight, including teaching strategies (methodologies), organization of the unit's time, topics of discussion for each class and student assignments. In this way, each unit takes into account the students' needs and possibilities. This means: 
- Considering the student (individual or group) role in the process of knowledge construction, which implies his or her and their participation in the definition and development of innovative content, methodologies and projects;

" Promoting "listening spaces" in our social practices (especially pedagogical), allowing discourses from as many people as possible to meet in the construction of knowledge;

- Recognizing the transformative role of human beings in the biosphere, deconstructing anthropocentric views in the construction of environmental knowledge;

" Using graphic expressions with a variety of "languages", allowing the development of interactive experiences in territorial topics of environmental education.

6. Consider cognitive and affective, ethical and aesthetic aspects: this characteristic could have been called "integral development", since it is characterized by the complete support (material, structural, pedagogical, psychological) to assure opportunities for the critical acquisition of multiple knowledge by the student (skills training, knowledge construction, production of different forms of expression, such as art, religion, philosophy, politics, etc.), considering their interests, capacities and difficulties (needs). This implies an approach that encompasses a global perspective, considering the individual as a complex whole and understanding that all elements pertinent to his formation are interrelated. This way, the individual presents himself as a social actor, a protagonist for society's cultural and historical changes. Environmental education, as a synthesis of expressive capacities, promotes a transversal educative message that induces or encourages "new" values of behavior (action).

7. Coherence and reconstruction between theory and practice: this characteristic covers the articulation between theory and practice as two necessarily complementary forms of the dynamic construction of knowledge. It also recognizes that social practices and theories are mutually steeped within specific cultural dynamics, and that these original cultural marks are always embedded in them. 
8. Forward-looking orientation of alternative scenarios: this characteristic is associated with the idea that citizenship can be a stable ground for actions aimed at the future. This implies the following ideas:

- Critical / reflective use of accessible and innovative techno-scientific resources;

- Construction of alternative scenarios for generating a future that moves towards sustainable practices;

- Reflection and commitment in the construction of new visions of science, society, technology and the environment aiming for responsible participation of present and future generations;

- Formation of critical professionals, open to new experiences and to alternative proposals for the management of society-nature relations;

- Social practices that more clearly define and reduce discriminatory and predatory relationships;

- Analyses of environmental problems caused by human actions.

9. Methodological adequacy: this characteristic is associated with the consistency, ethics and accuracy between the projected objectives and the suggested means by which they are to be achieved. To be consistent with the ideals of complexity, the curriculum's theoretical design should reflect a methodology that is consistent with the world view from where it originates. To that end, it should take into account disciplinary flexibility, reflexive-evaluative processes that favor the articulation between educational practices and theoretical postulations, participative methodologies and interdisciplinary contents.

10. Spaces for reflection and democratic participation: this characteristic is associated with the creation of spaces that allow for the participation of all individuals and groups, promoting encounters and approximations among them, especially those from different origins, to promote "exchanges in diversity". This has a direct effect in the generation of autonomy and in the thinking processes of everyone involved in the higher education scenario, thus, in the process of construction of knowledge itself. The acknowledgement of diversity is an essential element to making this process more democratic. 


\section{The "socially critical" and "post-critical" perspectives of curriculum}

The socially critical and post-critical framings of environmental education curriculum $^{9}$ and its research reflect a subtle but major transition in critical perspectives, approaches and practices in the discourse of education as they have evolved in the North from the 1980s to the present. Generally, the critical discourse of environmental education views itself as an "alternative" to much mainstream education. Social and environmental justice, hierarchical thinking, ideology critique, the deconstruction of instrumental reason and calculative rationality, and a commitment to praxis are major ingredients of a curriculum approach that "contests" rather than "reproduces" a range of inequities, injustices and power relations. More broadly, because of its interest in a social ecology and ecological socialism, partially inspired by the philosophical frame of ecocentrism (PAYNE, 2009), critical approaches to environmental education position the field as both a critique of unbridled anthropocentric modernity and its capitalism, and postmodernity and its socialism (SAUVÉ, 1999; HUCKLE, 1999) that, invariably, are shaped by the broader notion of neo-liberalism and, increasingly, academic/entrepreneurial capitalism. A major aim is to counter a wide range of social factors, arrangements and conditions, as well as historical, linguistic and cultural powers and forces that hegemonically and, therefore, "socio-ecologically" sustain various inequities, exclusions, injustices and oppressions. Noting its internal variations, the critical discourse of environmental education is a conceptually driven, theoretically informed and praxical reconceptualization of the unsustainable ethics and politics of 'sustainability' that persist in contemporary society. These 'contradictions of sustainability' recursively reconstitute the environmentally problematic human condition and various forms of social and ecological injustice. Paulo Freire's "pedagogies" has belatedly been drawn upon in the North's critical discourse of environmental education (KAHN, 2010; REID; PAYNE, 2011).

Here, because it is extremely important methodologically, we provide a short historical overview of the underlying principles, dimensions and normative interests of that ever evolving critical discourse of education as it has been modified, sometimes messily, in environmental education due to its peculiar cultural, social and ecological concerns. The framing of this critical discourse has been informed by a philosophically ecocentric purpose aimed at 
repairing, restoring or reconciling human-environment and culture-nature relations (PAYNE, 2009). Historicizing curriculum study through the tracking of the field's major transitions is, indeed, a central concern of the post-critical (HART, 2005) reframing of certain commitments made earlier within the socially critical perspective.

The genesis in Australian higher education and teacher education of what later was metaphorically named an education for the environment can be found in the pioneering work of a small group of academics working in curriculum studies in pre-service undergraduate teacher education at Deakin University in the State of Victoria in the late 1970s/early 1980s (TINNING; SIRNA, 2011) This curriculum "work" in the study of education, as it occurred theoretically in the academy, led to a critical curriculum approach in environmental education and an initial "model" (CASTRO, 1982) that was "alternative" to the mainstream "technocratic" or "applied science" approaches to curriculum whose linear models for "implementation" and prescriptions about knowledge in and about the environment were gaining ascendancy during the 1980s, particularly in the USA (ROBOTTOM, 1987, 2006). This alternative became known in the early 1990s as the "socially critical perspective" because it located the identification and resolution of environmental problems pragmatically within the social issues of the time and space, or place in which they were encountered. A problem-solving and constructivist epistemology was invariably pedagogically adopted, as was "action research" in academic methodology (ROBOTTOM, 2006). This "modern" socially critical alternative was committed in a transformative way to fostering both social and ecological justice, and to how its connections might be sustained in, by and through education praxis. In 1993, through the "Deakin-Griffith Environmental Education Project", four books were published that firmly established the "socially critical" discourse of environmental education (and "sustainability" to an extent) in Australia (FIEN, 1993a, 1993b; GREENALL GOUGH, 1993; ROBOTTOM; HART, 1993) and provided further impetus for other like-minded academics working prominently in the North/West who were developing their own contextually and geographically relevant curricula, pedagogy or research ${ }^{10}$.

Building upon that initial decade of critical curriculum theorizing, professional development, and action and participatory research in environmental education, the more recent transition to a "post-critical" framing of curriculum inquiry/study and research development occurred in the mid 
1990s, partially as a response to theoretical interest in poststructuralism (for example, GOUGH, 1994), including feminist perspectives (GREENALL GOUGH, 1993; BARRON, 1995) and renewed interest in phenomenological approaches (PAYNE, 1995). At about the same time, some limits to the socially critical curriculum were found and suggested the persistence of a theory-practice gap (for example, SPORK, 1992; WALKER, 1997) that earlier theorists tried to rectify by clarifying and then reworking, for example, the "contradictions" between environmental education purposes and practices in schooling (STEVENSON, 2007a). Concerns about contradiction persisted into the postcritical curriculum theorizing and have recently been revisited (STEVENSON, 2007b) more broadly and globally, including Gonzalez-Gaudiano's (2007) commentary on schooling and environment in Latin America. Moreover, the curriculum development of an education for the environment was sharply criticized for its allegedly coercive pedagogical implications (JICKLING; SPORK, 1998; FIEN, 2000). Finally, in the early 2000s the increasing use of the term "sustainability" attracted widespread debate and critique in environmental education circles.

The early socially critical theorists of environmental education, particularly in Australia, drew inspiration from the alleged "modern" critical theory of the Frankfurt School in Germany. These curriculum theorists focused on Habermas's views about "knowledge interests" and "ideology critique" and how those concepts informed the "contestation" of curriculum that previously was uncritically and atheoretically cast as a pernicious form of "social reproduction" (KEMMIS; FITZCLARENCE, 1986) incapable of dealing with a host of social issues, political interests and cultural challenges.

Five underlying principles of an alternative "counterhegemonic" approach to environmental education curriculum study and critique were developed but in specific relation to the professional development of teachers. Implications were clear for pre-service teacher education in environmental education as they were identified earlier when the curriculum was piloted in schools and for follow-up research development (CASTRO, 1982). These so-called "principles", are listed in each of the four Deakin-Griffith publications. They provided a "founding" layer of insight and practice. They persist in different ways in contemporary schooling and, for the purposes of this article, are understood to serve as a foundation for the transition from a "modern" perspective of socially critical curriculum to a "postmodern" post-critical set of perspectives. 
In synthesized form, these principles affirmed that alternative environmental education must be:

1. Enquiry-based: participants in professional development studies should be encouraged to adopt a research stance towards their own environmental education practices. Participants should be selfcritical of their beliefs and subject them socially to peer analysis and participant research for improvement.

2. Participatory and practice-based: curriculum development and professional development were viewed as interdependent. Such a professionally developed practice of human agency also demanded a self-empowering critique of the "structures" of the curriculum and professional development, including an examination of the "world views" that connect those actors' personal beliefs, social and educational ideologies, and the possibility for "false consciousness" within and between the educational institutions and their "hidden curriculum" influences.

3. Critical: an ideological critique was to be made of both the environmental and educational values and assumptions that inform environmental education policies, resources and practices. Knowledge interests were to be exposed so that the environmental educator could examine one's own curriculum and pedagogical practices. "Empowerment" of the educator was to be encouraged so as to make "changes".

4. Community based: environmental education should deal with "realworld" problems of relevance to the community in a "transformative" way that worked toward more ecologically sustainable social ends.

5. Collaborative: in which working with colleagues provided for forms of social knowledge and collective action that made it easier to recognize instances of false consciousness and institutional pressures that constrain the socially transformative practices of environmental education, or act against efforts to improve environmental education practices.

Much can now be said about the "knowledge interests" claimed in the principles. Word limits prevent a reflexive critique but the transition to a post-critical perspective of environmental education addressed some of the 
weaknesses or oversights of these principles and incorporated new theoretical developments. It can be said, however, that the five principles, individually and collectively, either assumed or epistemologically presumed a high degree of rational self-clarity in the professionally developed environmental education teacher, undergraduate student or curriculum specialist. Seen through the "emancipatory" and "transformative" imperatives of modern critical theory, the presumed epistemologies of rational self-clarity (and self-determining autonomy and authenticity) may ontologically underestimate the limits to change and socio-ecological transformation possibilities of education and curriculum, as they too are constrained geo-culturally and historically by the limiting factors shaping the agency (human) regulated by body/ies, the hold of tradition, the embedded power of force, and the contingencies of reflexivity (FAY, 1987; PAYNE, 1999).

The reframing of the post-critical perspective of environmental education curriculum theory and critique is partially indebted to, at least, two transitions in thought. The first is the rise of poststructural theory and its emphasis on the power/knowledge of language, discourse and text (for example, the thing called curriculum). The second is the retrieving of phenomenological perspectives in education that focus the curriculum and pedagogical emphasis ontologically and epistemologically on those felt, expressive, everyday embodied, embedded and ecologically "lived experiences". Together, these two movements of thought provided opportunities for curriculum theorists to "reframe" aspects of the socially critical perspective as a post-critical perspective (HART, 2005). This postmodern reframing more modestly "reimagines" some of the knowledge interests, ideological critiques, power relations and oppressive conditions emphasized in the somewhat modern "utopian" socially critical and "collectivist" perspective. These important academically driven transitions in thought, noting their internal variations such as feminist poststructuralism and ecophenomenology, have been accompanied by what Paul Hart refers to in environmental education research as "methodological expansion", via the emergence in the late 1990s/early 2000s of new genres of interpretive/qualitative inquiry in the social sciences (RUSSELL; HART, 2003) that, reflexively, inform new imaginaries in environmental education discourse, curriculum possibilities and pedagogical innovation (for example, McKENZIE, 2009). But, since they are academically-driven, post-critical (re)theorizations may reconstitute a "new" practice-theory gap, noting the limits on subjectivities (of teachers/schools) 
"regulated" practically by the highly localized contexts and globalizing forces shaping those local circumstances of schooling, curriculum and pedagogy.

In summary, against these changing backdrops of movements and transitions in thought, the authority/ies of knowledge, and the nationalization and globalization of curriculum, post-critical environmental education must also now contend with numerous "tensions" (or contradictions) locally, regionally, nationally and globally. It is, therefore, very difficult to identify, synthesize and summarize the key assumptions or principles of a "post-critical" approach to environmental education curriculum, inquiry and research. Indeed, most postcritical theorists of environmental education and research about it would resist any effort to extract and identify any foundational or essential understandings. Conceding the exploratory and problematic nature of the task of synthesizing a post-critical standpoint, we focus on a number of dimensions of the postcritical environmental education curriculum imaginary, and outline only some of the qualitative characteristics and issues arising.

We note openly here that these dimensions seem to flow into each other but that some underlying assumptions and qualities may sometimes be amorphous, or inconsistent, if not contradictory. This is part of the nature of post-critical theory. Nonetheless, the following dimensions of the post-critical approach provide a starting point from the North from which to re-engage debate not only about the virtues or problems of its socially critical predecessor and key informant (ROBOTTOM; HART, 1993) but also to set the scene for a critically reflexive dialogue with the South's ACES 10 characteristics of environmentalizing the curriculum.

Eclecticism, differencelotherness, plurality: This dimension involves a more heterogeneous opening to "different ways of knowing" and, in some instances, "different ways of being, doing and becoming" as is now acknowledged in curriculum for the persistent and critical purposes of democratically enhancing social inclusion and equity/justice, and often celebrated or imagined in pedagogy. Beyond the peculiar ecocentric and socio-ecological needs of environmental education, this pluralism is driven by:

Turns: the linguistic, discourse and textual "turn" fostered by poststructural thinking and how in curriculum, pedagogy and research things are "named", "de-centred" and "deconstructed" is now undergoing further reframing as the "material turn" (re)gathers momentum alongside a range of other interrelated turns that have quite specific consequences for environmental education 
curriculum dealing with human-environment and culture-nature relations. This new materialism includes an ecophenomenologically inspired return to highlighting the importance of the sensory/perceiving "body(ies)" and its/ their "placing" and "non-placing" in increasingly enigmatic spatio-temporal conditions. Given the South-North purposes of this paper, the philosophical renaissance in environmental education discourse of the ancient ideal of "cosmopolitanism" is significant.

Insiderloutsiders: recent turns challenge the parochialness of the discourse of environmental education. They give "outsider" impetus for the ongoing development of inter/transdisciplinary theorizations of social ecology and ecological socialism. Turns are driving expressive, conceptual, artistic and theoretical developments and provide new intellectual resources for curriculum that are flourishing in the (eco)humanities and in ecocriticism in literary and artistic (visual and performing) studies; (eco)phenomenology and ecopoetics including eco/artography; (eco)anthropology; (eco/environmental)psychology; environmental philosophy and philosophy of nature; environmental history; critical geographical and cultural studies; cognitive science and phenomenological philosophy as mind-embodied environmental perception and sensory/sensorium mobility; and messy interpretive methodologies in the human/social sciences.

Practices/groundings and theories and abstraction: the post-critical asks us to be clear about what is to be privileged. Is it the subject's standpoint and positioning, and their embodied inscriptions of history/culture as authentic or de-centred selves? Where does theory fit, and what role does it play? How might the post-critical curriculum theorist also deal with subjectivities when local, national, regional and global tensions are also inherent in conceptualizations and theorizations of social ecology and historical-geographic/cultural materialisms, discourses and texts. How might these tensions invoke and invite recognition of geo-epistemologically driven variations that "locate" knowledge and "position" the curriculum, and the increasingly postmodern cosmopolitan, mobile/fluid teacher, student, researcher and the researched in different timespace-place constructions? How will they be re-presented prior to or during their abstraction, mediation and globalization in increasingly virtual texts and discourses?

Aesthetics, ethics and politics: the preceding pluralities, turns, outsiders, groundings and abstraction transitions in thought, discourse and practice 
underpin the socio-ecological and historical-cultural/geographic demand for innovative/imaginary curriculum and pedagogical specialists and practitioners to post-critically engage a transdisciplinary ecology of an aesthetics, ethics and politics of environmental education. The post-critical challenge is to establish an ecoaesthetics/ethics/politics of environmental education curriculum that is also normatively "sustainable".

Realities/Truths/Facts/Values: knowledge, with its various conceptions and constructions, is now understood to be historically, culturally and subjectively contingent rather than authoritatively foundational, universal, unified and standardized. Meaning-making, interpretation and reinterpretation, and learning/knowing about the self, the social, culture and nature are more dynamically "relative" and "partial" or "incomplete". Different curriculum forms and pedagogical representations of knowledge (and research) make different claims on truth and reality, its certainty or partiality. Values are mediated by a range of factors and turns and are often subjectively and independently individualized and intensified in their "constructions". Skepticism emerges, science is understood as a human and social construction.

Ontologies-epistemologies and methodologies: the (messy) "politics" of multiple ontologies-epistemologies is acknowledged. The transition to a postcritical environmental/eco curriculum demands that educators, curriculum policy makers, school teachers and university professors be relatively clear about the ontological AND epistemological presuppositions they commit to, and be open about the limits they acknowledge in educational planning and practices before and during the methodological framing of curriculum, pedagogy and research. Clarification of the nexus between ontological considerations and epistemological issues is also responsive to the need to reconcile theory-practice gaps, mind-body dualisms and I-welifeworld contradictions. (Re)framing the politics of ontology-epistemology allows mounting a critical reflexivity about the internal coherence or commensurability in curriculum of the aims and purposes, means and processes and ends-in-view of environmental education.

Framing: post-critical environmental education curricula are made up of four interrelated and sequenced dimensions. They concern how curriculum and research address the demand for relative clarity about its (a) conceptualization (b) contextualization, locations and positioning (c) representation and interpretations, and (d) legitimization, explanation and justification. 
Agency and action: that of learners, classes, educators, families, neighborhoods, institutions and governments are not a predictable consequence of a formulaic and prescriptive view of knowledge "production", if the contingency and historicity of embodied and embedded beings and their consequential socio-ecological relations is ontologically taken more fully into account in relation to epistemological messiness and frailty.

\section{Final considerations}

We have already acknowledged the cosmopolitan (moral, ethical, political and institutional) challenges posed to this culturally comparative research that works across the Spanish, Portuguese and English languages and through the South-North and regional/national geo-cultural/historical epistemologies. So called "border crossings" will shape curriculum development in an increasingly globalizing world. As a temporary conclusion to this reflexive dialogue, we will simply outline some of the major "divergences" between the "Northern" critical and post-critical perspectives and the "Southern" ACES characteristics. In writing this article, we have consistently seen how language and text are only rough approximations of thinking and personal/cultural histories and, too often, the texts and discourse we have examined are far too general and "slippery".

There are many conceptual similarities and convergences between the South and North perspectives outlined above, and "complexity" and Freirean interests are clearly evident in many of these convergences. For example, there is broad agreement that a major purpose of environmentalized curricula is to contribute to the democratic transformation of the self and social and ecological relationships through careful, participatory inquiry conducted by subjects/ learners in various "embedded" environments or places whose "localness" is always and increasingly shaped by larger, pervasive often pernicious neoliberal derived global concerns. There is broad agreement in the South-North dialogue that an environmentalized curriculum should pedagogically build a theory and practice bridge in reinstating a well informed sense of individual and collective agency and action. There is agreement that curriculum must incorporate aesthetic, ethical and political qualities in a far more "meaningful" way if an environmentalized curriculum is to be more "valued" and valuable in promoting and engaging learning. This "ecology" of learning demands creative visions and versions of inter- and transdisciplinarity in the methodologies of 
curriculum generation and development that carry through ontologically and epistemologically in their particular enactments in appropriate geo-cultural/ historical settings. If we had more space, we would ask more specifically of the critical environmental educator - what "experiences" are pedagogically designed within the curriculum that best promote student meaning-making and engagement before formal or official "learning" occurs? There is agreement that these significant challenges and "imaginings" or world views for an environmentalized curriculum are "complex", "messy" and often only partial where educational "certainty" is no longer possible. Once, again with more space, it would be important to raise the difficult question of what enabling conditions of praxis need to be recreated for curriculum developers, teachers and student/learners to move, in action, beyond these mere language/discursive/ textual "moves" in environmental education.

As a temporary conclusion, we offer five issues for reflection. It is not immediately clear to us from the general ACES characteristics how the environmentalization of curriculum might more assertively incorporate certain aspects of the socially critical and post-critical perspectives:

- Historicization of curriculum and educational reform. The ACES characteristics are largely an international "Latin" product developed by academic representatives from some European and South American institutions and nations. While these characteristics include many "critical" ideas in curriculum, there is always the risk that the historical memory of, for example, Freire is diluted, abstracted or ignored. From the North, we have "traced" the transition of the Anglo-speaking socially critical into the post-critical, reiterating belated interest in Freire's work exists.

- Techno-scientific knowledge and systems. Our interpretation of the ACES framework suggests it implicitly promotes or supports an environmentalized curriculum consistent with a rationalist "applied science" approach. In particular, the North's socially critical perspective was strongly opposed to the "instrumental reason" logic and "calculative rationality" imperatives of the applied science approach to curriculum which was viewed, critically, as providing only for disembodied, disembedded and, inevitably, depoliticized and abstracted knowledge about the environment and not for/with the environment. 
- Body/experience/expression "ways of doing and knowing". The ACES framework is not very clear on how the perceiving/sensing and feeling/ knowing "body(ies)" acts as a curriculum inquiry "site" and "setting". The post-critical perspective has heightened (eco)phenomenological interest in the body (inner nature) as a "lived" source and expressive/ aesthetic focus of (globalized) inquiry. This has partially been driven by the "(inter)corporeal turn" need to deconstruct the Cartesian inspired mind-body and I-we-world dualisms that, often through the applied science approach to environmental education curriculum, hamper socio-"ecological" approaches to more ecocentric living, meaningmaking, valuing and learning.

- Truths, subjectivity, agency/action. Despite the ACES commitments to complexity, the post critical perspective is more assertive about the plurality, ambiguities, relativities, partiality and contingency in "knowledge" generation, production, dissemination, "downloading" and "uptaking". There appears to be a greater "acceptance" of uncertainty and messiness rather than certainty and tidiness of the curriculum. For educators, this messiness presents a challenge that many educational rationalists will be uncomfortable with. On the other hand, socially and post-critical environmental educators challenge the certainty of the applied science approach that claims to provide the "right" knowledge, which will shape individualized beliefs, attitudes and values and, propositionally, the "right" proenvironmental behaviors. The evidence supporting that instrumental/ calculative curriculum logic and practice is scarce. Agency as praxis, treated critically, might occur more appropriately and adequately through the educative intersections of an aesthetics, ethics and politics of curriculum design and pedagogical implementation

" The nature of curriculum as "environmental design" (HUEBNER, 1967/1987). Our three dialogic partners - ACES, the socially critical and post-critical - are somewhat "silent" on the "environmental" and "ecological" design of the curriculum, thus complicating the already enigmatic nature of time-space-place considerations in environmental education research (PAYNE, 2003). Often, while there might be a "social" or "personal" design consideration in the curriculum framing and document, it is not clear how and in what ways "environment" 
or nature, or versions of them and their "times" are being represented. There remains a great deal of work to be done, it appears, in both South and North, for the educationalist, curriculum developer and pedagogue to carefully elaborate the meanings of the intersections of the terms "environment" and "education" in ways that are more consistent with the post-critical call for an (eco)aesthetics, ethics and politics of this curriculum field. This challenge becomes more complicated when we examine the difficulties of "environmentalizing the curriculum" in mathematics, or physical education, or chemistry, or literature. But, as previously mentioned, there has been an explosion of interest in the past decade in, for example, the ecohumanities, arts and even environmental engineering. An increasing amount of intellectual resources are available. At the same time, there are deep concerns about how the curriculum in many countries is increasingly being shaped by the corporate university and the "academic capitalism" of the neo-liberal governmentality and disciplining of most institutions.

Overall, the ACES characteristics are very broad and open to interpretation, as are the somewhat elusive dimensions of the post-critical. The interpretation of their language and texts is a formidable challenge, which is certainly exacerbated by the difficulties of bringing together contributions from such different actors from such different regions (even though the participating institutions were self selected, the specific local/national/regional characteristics are very evident in the ACES Network's publications, especially in the description of the 10 characteristics of an "environmentalized study" by the different universities).

We offer a strong warning. This "broadness" of definition, of conceptualization, of characteristics, dimensions and qualities makes it possible to "fit" any practice and/or theory into the ideals and purposes of an environmentalized curriculum. There is the strong possibility that the looseness of language and text makes that discourse more vulnerable to orthodox, conservative, regressive or reactionary "re-colonizations" of the critical aspirations of environmental education, thus, to use Aldo Leopold's (1989, p. 210) declaration, "in our attempt to make conservation easy, we have made it trivial". The same thing can possibly be said of the environmental education imaginary. If we are not cautious, we can wind up encouraging a 
"greenwashed" approach to the environmentalization of curriculum in higher education through neo-liberal and global reform efforts. On the other hand, given the criticality we encourage in our "framing" and conceptualization/ contextualization of this cosmopolitan-like South-North dialogue, we remain cautious about the complexity of achieving all the elements of what would be considered an environmentalized curriculum. If so, this complexity might perpetuate the everlasting theory-practice gap in environmental education.

We anticipate, therefore, that the "historicized" approach undertaken in this South-North dialogue will bring to the fore of discussion and debate about environmentalizing the curriculum some of the "best" insights available to us in terms of "critically" developing an educational, curriculum and research response to the environmentally problematic human condition.

\section{Notes}

1 Red ACES: Ambientalización Curricular de los Estudios Superiores (Curricular Environmentalization of Higher Education Network).

2 América Latina - Formación Académica (Latin America - Academic Formation).

3 The participating Universities were: Universitat Autónoma de Barcelona (UAB - Spain); Universidad Nacional de San Luis (UNSL - Argentina); Universidad Nacional de Cuyo (UNCu - Argentina); Universidade Federal de São Carlos (UFSCar - Brazil); Universidade Estadual Paulista, Campus Rio Claro (UNESP-Rio Claro - Brazil); Universidade Estadual de Campinas (UNICAMP - Brazil); Universidad de Pinar del Río (UPR - Cuba); Universidade de Aveiro (UA - Portugal); Universitat de Girona (UdG - Spain); Technical University of Hamburg (TUTECH - Germany); Universitá degli studi del Sannio (UNISANNIO - Italy).

4 The idea of a "happening" (FOUCAULT, 2006) rests in the emergence of new lines of thought that result in a series of occurrences (happenings) related to a common phenomenon, causing questioning and "instability" in "naturalized" concepts and social processes. From these occurrences new discourses and practices germinate. Therefore, new objects of knowledge arise, especially in the face of conflicts and controversies between emerging speeches and practices. 
5 To learn more about the ALFA Programme go to: <http://ec.europa.eu/ europeaid/where/latin-america/regional-cooperation/alfa/index_pt.htm>.

6 We do recognize that there are other important theories that play an important role in the development/"shaping" of Brazilian environmental education discourses such as, for example, Marxism. However, even if we acknowledge that these theories effect the development of environmental education discourses differently in the south and in the north, they seem to have a more global impact, while the highlighted theories (Freire and Morin) seem to play a more incisive role in the "Latin" perspective.

7 Critical scholars contributing to this edited book (BRASIL, 2004) include Isabel C. M. Carvalho, Mauro Guimarães, Maria R. Avanzi, Aloísio Ruscheinsky, Carlos F. B. Loureiro, Gustavo F. C. Lima, José S. Quintas, Déborah Munhoz. To the best of our knowledge, these critical scholars have not commented or critiqued the ACES framework.

8 The leading author speaks/writes in English, has a basic understanding of Spanish and a modest understanding of Portuguese. The co-author speaks/ writes in Portuguese and English, and has a good understanding of Spanish. The former has presented environmental education research workshops, seminars and a keynote conference address in Brazil in 2009 as well as having published in "Pesquisa em Educação Ambiental", while the latter, at the time of writing this article, was studying for his $\mathrm{PhD}$ in Australia for a six month period under the supervision of the leading author.

9 It is important to point out that this paper does not aim to analyze overall curriculum theory. It does however aim to create a south-north dialogue that puts into evidence some of the particularities of the socio-environmental design of curricula that aim to either integrate or infuse disciplinary, multidisciplinary, cross-disciplinary, interdisciplinary and transdisciplinary natures of "environmental" and "educational" knowledge into pre-existing forms (or disciplines).

10 For example, in the UK (John Huckle, Stephen Sterling, William Scott, Alan Reid), Europe (Regula, Peter Posch, Bjarne Jensen, Karsten Schnack, Soren Breiting, Arjen Wals, Jeppe Laessoe), Canada (Paul Hart, David Jardine, Lucy Sauvé, Leesa Fawcett, Connie Russell), Southern Africa (Heila Lotz-Sisitka, Rob O’Donoghue, Lesley Le Grange, Leigh Price), USA (Bill Stapp, Bob Stevenson, Chet Bowers). 


\section{REFERENCES}

ARBAT, E.; GELI, A.M. (Ed.). Ambientalización Curricular de los Estudios Superiores: aspectos ambientales de las universidades. Girona: Universitat de Girona-Red ACES; Servei de Publicacions, 2002. (Colección Diversitas, n. 32).

BARRON, D. Gendering environmental education reform: identifying the constitutive power of environmental discourses. Australian Journal of Environmental education, Lismore, NSW, Australia, v. 11, p. 107-120, 1995.

BLUDHORN, I. The politics of unsustainability: COP15, post-ecologism, and the ecological paradox. Organization \& Environment, v. 24, n. 1, p. 3453, 2011.

BONIL, J. et al. Un nuevo marco para orientar respuestas a las dinámicas sociales: el paradigma de la complejidad. Investigación en la Escuela, Sevilla, Spain, n. 53, p. 5-20, 2004.

BRASIL. Ministério do Meio Ambiente. Diretoria de Educação Ambiental. Identidades da educação ambiental brasileira. Brasília: MMA, 2004. p. 25-34.

CANAPARO, C. Geo-epistemology: Latin America and the location of location of knowledge. Oxford, UK: Peter Lang, 2009.

CASTRO, A. et al. Environmental Education Study Guide 1 and 2. Geelong, Australia: Deakin University, 1982.

FAY, B. Critical social science: liberation and its limits. New York: Cornell University Press, 1987.

FIEN, J. Education for the environment: a critique-an analysis.

Environmental Education Research, Oxon, UK, v. 6, n. 2, p. 179-192, 2000.

FIEN, J. Education for the environment: critical curriculum theorizing and environmental education. Geelong, Australia: Deakin University, 1993a.

FIEN, J. (Ed.). Environmental education: a pathway to sustainability. Geelong, Australia: Deakin University, 1993b.

FOUCAULT, Michel. Estratégia, poder-saber. Rio de Janeiro, RJ: Forense Universitária, 2006. 
GELI, A. M.; JUNYENT, M.; SÁNCHEZ, S. (Org.). Ambientalización Curricular de los Estudios Superiores: acciones de intervención y balance final del proyecto de ambientalización curricular de los estudios superiores. Girona: Universitat de Girona-Red ACES; Servei de Publicacions, 2004. (Colección Diversitas, n. 49).

GELI, A. M.; JUNYENT, M.; SÁNCHEZ, S. (Org.). Ambientalización Curricular de los Estudios Superiores: diagnóstico de la ambientalización curricular de los estudios superiores. Girona: Universitat de Girona-Red ACES; Servei de Publicacions, 2003 (Colección Diversitas, n. 46).

GONZALEZ-GAUDIANO, E. Scholling and environment in Latin America in the third millenium. Environmental Education Research, Oxon, UK, v. 13, n. 2, p. 155-170, 2007.

GOUGH, N. Playing at catastrophe: ecopolitical education after poststructuralism. Educational Theory, Champaign, IL, USA, v. 44, n. 2, p. 189-210, 1994.

GREENALL GOUGH, A. Founders in environmental education. Geelong, Australia: Deakin University, 1993.

HART, P. Transitions in thought and practice: links, divergences and contradictions in post-critical inquiry. Environmental Education Research, Oxon, UK, v. 11, n. 4, p. 391-400, 2005.

HUCKLE, J. Locating environmental education between modern capitalism and postmodern socialism: a reply to Lucy Sauvé. Canadian Journal of Environmental Education, Ontario, Canadá, v. 4, p. 36-45, 1999.

HUEBNER, D. Curriculum as a concern for man's temporality. Theory into Practice, Oxon, UK, p. 324-331, 1967/1987.

JICKLING, B.; WALS, A. Globalization and environmental education: looking beyond sustainable development. Journal of Curriculum Studies, Oxon, UK, v. 40, n. 1, p. 1-21, 2008.

JICKLING, B.; SPORK, H. Education for the environment: a critique. Environmental Education Research, Oxon, UK, v. 4, n. 3, p. 309-328, 1998.

JUNYENT, M.; GELI, A. M.; ARBAT, E. (Ed.). Ambientalización Curricular de los Estudios Superiores: proceso de caracterización de la ambientalización curricular de los estudios universitarios. Girona: 
Universitat de Girona-Red ACES; Servei de Publicacions, 2003. (Colección Diversitas, n. 40).

KAHN, R. Critical pedagogy, ecoliteracy, \& planetary crisis. New York: Peter Lang, 2010.

KEMMIS, S.; FITZCLARENCE, L. Curriculum theorizing: beyond reproduction theory. Geelong, Australia: Deakin University, 1986.

KENWAY, J.; FAHEY, J. (Ed.). Globalizing the research imagination. London: Routledge, 2009.

LEOPOLD, A. A sand county almanac: and sketches here and there. New York: Oxford University Press, 1987.

LOTZ-SISITKA, H. Changing social imaginaries, multiplicities and 'one sole world'. Environmental Education Research, Oxon, UK, v. 16, n. 1, p. 133-142, 2010.

LYOTARD, J-F. The postmodern condition: a report on knowledge. Minneapolis: University of Minnesota Press, 1984.

McKENZIE, M. et al. Fields of green: restoring culture, environment, and education. Cresskill: Hampton Press, 2009.

PAVESI, A. A ambientalização da formação do arquiteto: o caso do Curso de Arquitetura da Escola de Engenharia de São Carlos (CAU, EESC-USP). 2007. 199 p. Tese (Doutorado em Educação) - Universidade Federal de São Carlos, São Carlos, 2007.

PAYNE, P. The globally great moral challenge: ecocentric democracy, values, morals and meaning. Environmental Education Research, Oxon, UK, v. 16, n. 1, p. 153-171, 2010.

PAYNE, P. Framing research: conceptualization, contextualization, representation and legitimization. Pesquisa em Educação Ambiental, São Carlos, SP, Brazil, v. 4, n. 2, p. 49-77, 2009.

PAYNE, P. Postphenomenological enquiry and living the environmental condition. Canadian Journal of Environmental Education, Ontario, Canada, p. 169-190, 2003. 
PAYNE, P. Postmodern challenges and modern horizons: education 'for being for the environment'. Environmental Education Research, Oxon, UK, v. 5, n. 1, p. 5-34, 1999.

PAYNE, P. Ontology and the critical discourse of environmental education. Australian Journal of Environmental Education, v. 11, p. 83-106, 1995.

REID, A.; PAYNE, P. Producing knowledge and (de)constructing identities: a critical commentary on environmental education and its research. British Journal of Sociology of Education, London, UK, v. 32, n. 1, p. 155-165, 2011.

REID, A.; PAYNE, P. Handbooks of environmental education research: for further reading and writing. In: BRODY, M. et al. International Handbook of Research in Environmental Education. New York: Routledge, 2012. .

ROBOTTOM, I. Participatory research in environmental education: some issues of epistemology and methodology. Pesquisa em Educação Ambiental, São Carlos, SP, Brazil, v. 1, n. 1, p. 11-25, 2006.

ROBOTTOM, I. (Ed.). Environmental Education: practice and possibility. Geelong, Australia: Deakin University, 1987.

ROBOTTOM, I.; HART, P. Research in environmental education: engaging the debate. Geelong, Australia: Deakin University, 1993.

RUSSELL, C; HART, P. Exploring new genres of inquiry in environmental education research. Canadian Journal of Environmental Education, Ontario, Canada, v. 8, p. 5-8, 2003.

SAUVÉ, L. Uma cartografia das correntes em educação ambiental. In: SATO, M.; CARVALHO, I. M. (Org.). Educação Ambiental: pesquisa e desafios. Porto Alegre: Artmed, 2005. p. 17-46.

SAUVÉ, L. Environmental education: possibilities and constraints. Connect. UNESCO International Science, Technology \& Environmental Education Newsletter, Paris, France, v. 27, n. 1/2, p. 1-4, 2002.

SAUVÉ, L. Environmental education between modernity and postmodernity: searching for an integrating educational framework. Canadian Journal of Environmental Education, Ontario, Canadá, v. 4, p. 9-35, 1999. 
SPORK, H. Environmental education: a mismatch between theory and practice. Australian Journal of Environmental Education, v. 8, p. 147-166, 1992.

STEVENSON, R. Schooling and environmental education: contradictions in purpose and practice. Environmental Education Research, Oxon, UK, v. 13, n. 2, p. 139-154, 2007a.

STEVENSON, R. Overview. Environmental Education Research, Oxon, UK, v. 13, n. 2, p. 129-138, 2007 b.

SUND, L.; OHMAN, J. Cosmopolitan perspectives on education and sustainable development: between universal ideals and particular values. Ultbilding \& Demokrati, Orebro, Sweden, v. 20, n. 1, p. 13-34, 2011.

TINNING, R; SIRNA, K. (Ed.). Social justice, education and the legacy of Deakin University. Rotterdam: Sense Publications, 2011.

WALKER, K. Challenging critical theory in environmental education.

Environmental Education Research, Oxon, UK, v. 3, n. 2, p. 155-162, 1997. 


\section{Ambientalizando o currículo: um crítico diálogo Sul-Norte}

\section{Resumo}

A questão de como a ambientalizaçáo do currículo pode ocorrer de forma sustentável na educação superior tornou-se uma preocupação local, nacional, regional e global para educadores ambientais, especificamente, e educadores de maneira geral. O framework contemporâneo da rede ACES inclui dez características de ambientalização consideradas adequadas para incorporação nos programas de educação de professores, e tem sido adotado em algumas universidades públicas brasileiras entre outras da América Latina e Europa. O framework da Rede ACES foi desenvolvido por um grupo de acadêmicos "latinos" da Europa e América Latina. Trazemos esse influente framework em diálogo crítico com o desenvolvimento de perspectivas "socialmente críticas" e "pós-críticas" no currículo de educação ambiental de acordo com investigaçóes sobre como esses discursos críticos têm sido desenvolvido no "Anglo-Norte" nos últimos trinta anos. Reflexivamente, identificamos um número de semelhanças e diferenças chaves no âmbito do diálogo Sul-Norte. Educadores, especialistas em currículo e pesquisadores do Brasil, para quem este artigo é prioritariamente escrito, podem refinar ainda mais as possibilidades críticas do framework da Rede ACES em seus esforços para ambientalizar o currículo. De modo geral, este artigo exemplifica uma abordagem "não colonial" de globalização do discurso da educaçáo ambiental.

Palavras-chave: Educação Ambiental. Teorias do currículo. Educação superior.

\section{Ambientalizando el currí- culum: un crítico diálogo Sur-Norte}

\section{Resumen}

La cuestión de cómo la ambientalización del currículo puede ocurrir de forma sostenible en la educación superior se ha convertido en una preocupación local, nacional, regional y global para educadores ambientales, específicamente, y educadores en general. El marco contemporáneo de la Red ACES incluye diez características de ambientalización que son consideradas adecuadas para incorporación en los programas de formación docente, y ha sido adoptado en algunas universidades públicas brasileñas entre otras de América Latina y Europa. El marco fue desarrollado por un grupo de estudiosos "latinos" de Europa y América Latina. Traemos este influente marco en diálogo crítico con el desarrollo de las perspectivas "socialmente crítica" y "pos-críticas" del currículo de educación ambiental de acuerdo con las investigaciones sobre cómo estos discursos críticos se han desarrollado en la "Anglo-Norte" en los últimos 30 años. Reflexivamente, se identificaron un número de similitudes y diferencias claves en el marco del diálogo Sur-Norte. Educadores, especialistas de currículo e investigadores de Brasil, para quien este artículo es prioritariamente escrito, pueden refinar más las posibilidades críticas do marco de la Red ACES en sus esfuerzos para ambientalizar el currículo. En General, este artículo ejemplifica una abordaje "no colonial" de la globalización del discurso de la educación ambiental.

Palabras clave: Educación Ambiental. Teorías del currículo. Educación superior. 
Phillip G. Payne

E-mail: phillip.payne@monash.edu

\section{Cae Rodrigues}

E-mail:cae_jah@hotmail.com

Recebido em: 30/3/2012

Versáo final recebida em: 17/5/2012

Aprovado em: 1/6/2012 